\title{
Brood Movements of Eastern Prairie Population Canada Geese: Potential Influence of Light Goose Abundance
}

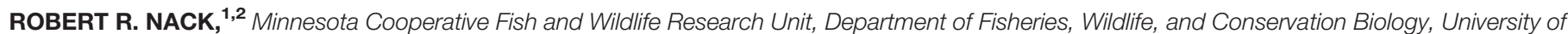 \\ Minnesota, St. Paul, MN 55108, USA

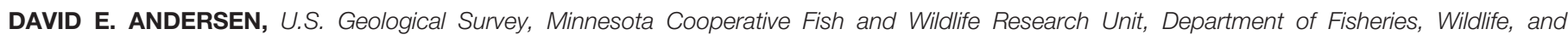 \\ Conservation Biology, University of Minnesota, St. Paul, MN 55108, USA
}

\begin{abstract}
During the summers of 2000-2002, we used radio telemetry to document Eastern Prairie Population (EPP) Canada goose (Branta canadensis interior) brood movements and use of brood-rearing habitat. We compared these data with similar data collected in 1976-1978 (Didiuk 1979), prior to a significant increase in the size of the midcontinent light goose (lesser snow geese [Chen caerulescens] and Ross's geese [C. rossii]) population and consequent habitat alteration near Cape Churchill, Manitoba. Since the late 1970s, use of traditional EPP Canada goose broodrearing areas by light geese has increased significantly near Cape Churchill, and the density of nesting EPP Canada geese has declined. Alteration of brood-rearing habitat has been hypothesized as a cause of the decline in EPP breeding density, as natal dispersal to more distant brood-rearing areas may influence future recruitment into the local breeding population. In 1976-1978, 20 (95\%) of 21 radio-marked broods nesting in beach ridge/sedge meadow habitat moved to salt marsh brood-rearing areas; however, only 5 (19\%) of 27 Canada geese, nesting in the same habitat, made initial movements to these traditional salt marsh brood-rearing areas in 2000-2002. In 2000-2002, 30 (75\%) of 40 geese with broods made initial movements to beach ridge/sedge meadow habitat-10 of these broods eventually moved to salt-marsh habitats later in the brood-rearing period ( $\bar{\chi}$ date $=22$ days postmedian hatch). Mean brood home range size from 2001-2002 in coastal and inland habitats nearly doubled compared to the mean brood home range size during 1976-1978. Eastern Prairie Population Canada geese currently use broodrearing habitat other than the coastal salt marshes they used prior to habitat alteration resulting from foraging by light geese. A shift in the use of brood-rearing habitat could potentially reduce nest densities on the study area if first-time breeders nest closer to distant brood-rearing areas. The impact of alternative brood-rearing habitat on gosling growth and survival for EPP geese is unknown, but foraging in poorer quality broodrearing habitat may also contribute to the observed decline in nesting density. (JOURNAL OF WILDLIFE MANAGEMENT 70(2):435-442; 2006)
\end{abstract}

\section{Key words}

Branta canadensis, brood, Canada geese, Chen caerulescens, Eastern Prairie Population, Hudson Bay, light geese, Manitoba, telemetry.

From the late 1960s to the mid-1990s, the midcontinent population (MCP) of lesser snow geese increased in size 3-fold (Abraham et al. 1996, Abraham and Jefferies 1997). This dramatic increase in the number of light geese (lesser snow geese and Ross's geese) was accompanied by significant habitat alteration in the Arctic and sub-Arctic as a result of grazing and grubbing by geese (summarized in Abraham and Jefferies 1997). In southern James and Hudson Bays, upwards of $35 \%$ of salt- and freshwater marshes have been destroyed, and another 30\% have been severely damaged as a result of grazing and grubbing by geese (Abraham and Jefferies 1997). It is not clear how long it will take for these arctic habitats to recover in the absence of high foraging pressure by geese, but minimum estimates of 30-50 years have been suggested (summarized in Batt 1997).

Consequences of high numbers of light geese and concurrent habitat alteration on other species are not well documented (e.g., Ankney 1996). Nesting southern James Bay population (SJBP) Canada geese (B.c.interior) on Akimiski Island, Nunavut, Canada have been recently investigated in the context of potential impacts of light geese (Leafloor et al. 1998, Hill 1999, Hill et al. 2003, Gleason et al. 2004). Leafloor et al. (1996) reported a decline in direct recovery rates of juvenile Canada geese banded on Akimiski Island since 1987 and suggested that gosling mortality in late

\footnotetext{
1 E-mail: Robert.R.Nack@aphis.usda.gov

2 Present address: USDA/APHIS/Wildlife Services, Waupun, WI 53963, USA.
}

summer or early fall is related to the effects of chronic malnutrition due to habitat alteration. Gleason et al. (2004) documented reduced reproductive parameters for SJBP Canada geese nesting sympatrically with lesser snow geese on Akimiski Island. These data suggest that habitat alteration in traditional brood-rearing areas may be limiting recruitment of SJBP Canada geese. Similar factors may be influencing EPP Canada geese, although effects of habitat alteration on EPP Canada goose recruitment have not been well studied.

From 1976 to 1996, nesting density of EPP Canada geese near Cape Churchill declined by a factor of 4.5 and has remained low (near 5 nests per 100 ha of nesting habitat) since 1996 (Allen 1996, Walter 1999; D. E. Andersen, Minnesota Cooperative Fish and Wildlife Research Unit, St. Paul, Minn., USA, unpublished data). Historically, nesting EPP Canada geese outnumbered nesting lesser snow geese on this study area-only recently have $>2$ snow goose nests been located during nest searching on the study area (55 in 2001, 6 in 2002, and 94 in 2003; D. E. Andersen, Minnesota Cooperative Fish and Wildlife Research Unit, St. Paul, Minn., USA, unpublished data). However, habitat alteration in the nearby La Pérouse Bay snow goose colony (Fig. 1) has resulted in snow geese moving their broods long distances $(>10 \mathrm{~km})$ to forage in salt marsh habitats on the study area that were formerly used primarily by EPP Canada geese for brood rearing (Cooch et al. 1993, Ganter et al. 1996, Jano et al. 1998, Walter 1999, Sammler 2001). Helicopter surveys of 15 traditional EPP brood-rearing areas revealed a dramatic increase in the number of snow geese 


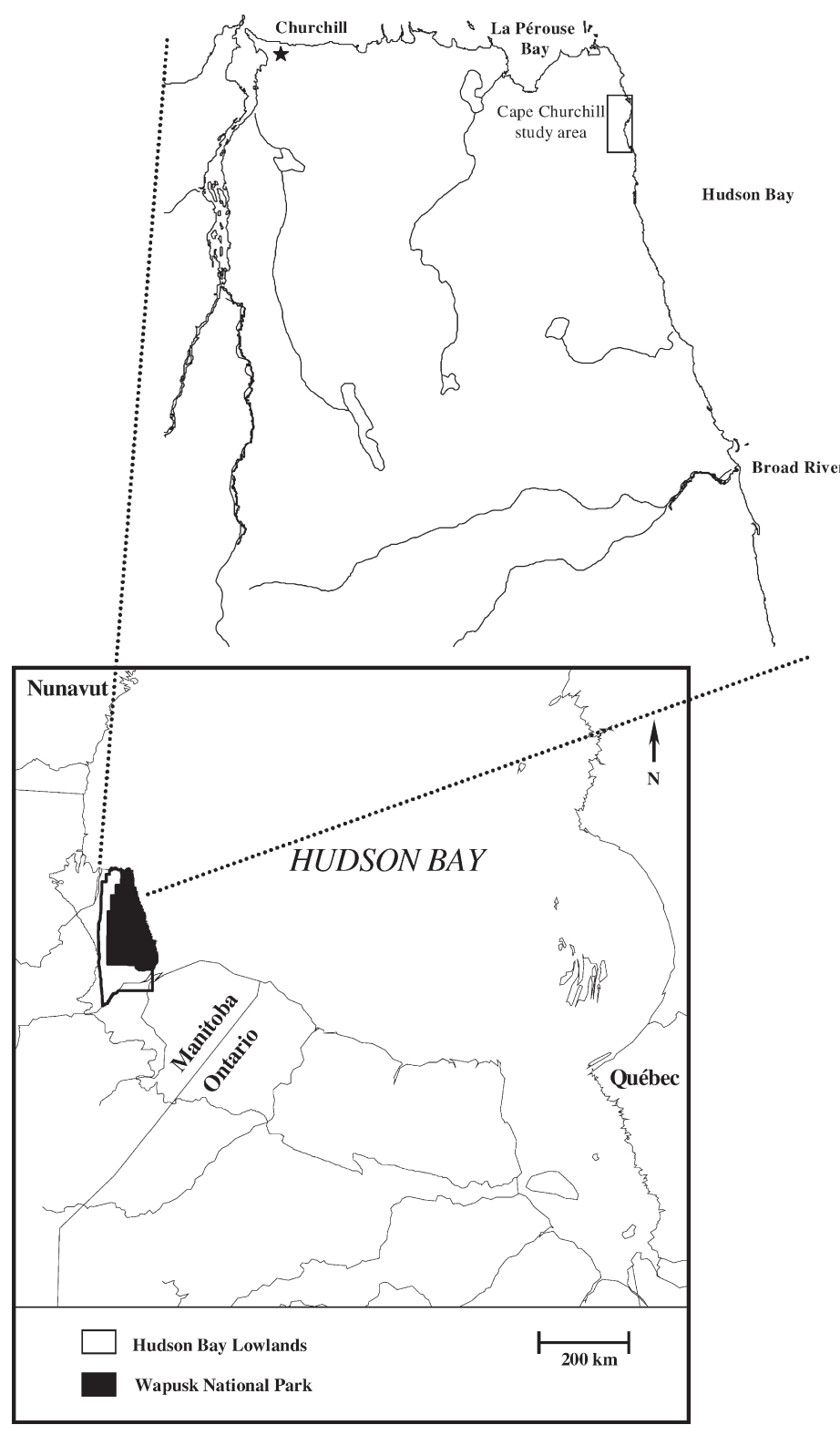

Figure 1. Cape Churchill study area (Nestor One) in relation to the town of Churchill, La Pérouse Bay, and the mouth of the Broad River, Manit., Canada.

between $1977(\bar{\chi}=2.02, \mathrm{SE}=1.56)$ and $2002(\bar{\chi}=45.93, \mathrm{SE}=$ 17.74) and that light geese currently outnumber Canada geese 3.5 to 1 during the brood-rearing period (Nack and Andersen 2004). Foraging activities of migrating, nesting, and molting geese (Canada and light geese) coupled with large numbers of light geese during brood rearing has lead to a long-term change in vegetation on traditional EPP brood-rearing areas (Walter 1999, Sammler 2001). Walter (1999) hypothesized that alteration of brood-rearing habitat by geese may have contributed to decreased nesting density of EPP Canada geese on the study area.

Neither the effect of light geese on specific brood-rearing habitats, nor the direct or indirect effects of light geese on nesting EPP Canada geese have been intensively studied (Walter 1999). Didiuk (1979) documented the distribution and movements of EPP Canada goose broods at Cape Churchill, prior to use of EPP brood-rearing areas by high densities of light geese and the presence of nesting snow geese on the study area. Data exist on lesser snow geese at La Pérouse Bay and on EPP Canada geese at Cape Churchill for the last 25 years, making it possible to investigate the effects of increasing densities of light geese on Canada geese during the brood-rearing period (Rusch et al. 1996). Our objectives were to document current patterns of use of broodrearing habitats by Canada geese (in the presence of light geese), compare those patterns to historical patterns (in the absence of light geese and significant brood-rearing habitat alteration), and provide a description of the habitat in current Canada goose brood-rearing areas.

\section{Study Area}

The EPP breeding range encompasses approximately $54,000 \mathrm{~km}^{2}$ in northern Manitoba with the highest densities of breeding Canada geese observed in a narrow strip of coastal habitat adjacent to Hudson Bay (Malecki 1976, Walter 1999). The Cape Churchill (Nestor One) study area was located within this coastal strip of tundra habitat and the intensively searched core study area (48 $\mathrm{km}^{2}$ ) was within $5 \mathrm{~km}$ of the Hudson Bay coastline (Allen 1996, fig. 1). The Nestor One base camp was approximately $60 \mathrm{~km}$ eastsoutheast of the town of Churchill, Manitoba, Canada, and located within Wapusk National Park $\left(11,475 \mathrm{~km}^{2}\right)$. The study area was within the Hudson Bay Lowland region and was characterized by low relief, continuous permafrost, poor drainage, numerous relict beach ridges, coastal marshes, and coastal tundra vegetation (Wellein and Lumsden 1964, Walter 1999). Major habitat types included coastal salt marsh, beach ridge/sedge meadow, and interior sedge meadow (Didiuk 1979).

Intertidal coastal salt marshes, approximately $0.5 \mathrm{~km}$ wide, were found in discrete areas adjacent to Hudson Bay and near the mouths of streams. Canada geese with broods intensively grazed swards of Puccinellia phryganodes and Carex supspathachea that historically dominated these areas at Cape Churchill (Didiuk 1979, Walter 1999). Although Puccinellia phryganodes was still found in small quantities, the salt-marsh habitat of the study area had shifted to a complex dominated by moss (Amblystegium tenax) and willow (Salix brachycarpa; L. Punter, University of Manitoba, Winnipeg, Manit., Canada, personal communication). Foraging activities of large numbers of geese during the breeding season quickly reduced available vegetation to the ground level.

Beach ridge/sedge meadow habitat consisted of freshwater sedge meadows and lakes between sand and gravel relict beach ridges that paralleled the coastline and extend approximately $5 \mathrm{~km}$ inland from Hudson Bay. Freshwater sedge meadows located between beach ridges were dominated by sedges (primarily Carex aquatalis) and moss (mostly Sphagnum spp.) in wet areas. Interior sedge meadow habitat began at the end of the beach ridge/sedge meadow habitat (approx. $5 \mathrm{~km}$ inland) and extended another $15 \mathrm{~km}$ inland to the tree line. Large lakes surrounded by a lowland shrub community, few dry upland areas, and extensive freshwater sedge meadows characterized interior sedge meadow habitat. Areas altered by intense shoot pulling by geese (Kotanen and Jefferies 1997) occurred in both the beach ridge/sedge meadow and interior sedge meadow habitats. For a more complete description of vegetation and landforms associated with the Hudson Bay lowlands and Wapusk National Park, see Brook (2001). 


\section{Methods}

\section{Nest Searching}

We divided the core study area into 23 intensively searched units, with boundaries identified by beach ridges, lakes, or the coast of Hudson Bay. We searched all units once during each of the 20002002 field seasons, and units in beach ridge/sedge meadow habitats have been intensively searched annually since 1976 (Rusch et al. 1996). To locate nests, 6 investigators distributed themselves across an entire unit, traversed the unit in parallel, and used binoculars to aid in locating Canada goose and other bird nests. On initial nest visits, we used a combination of egg floating (Westerkov 1950, Walter and Rusch 1997) and candling techniques (Weller 1956) to calculate nest age. In addition, we recorded universal transverse mercator (UTM) coordinates of nests from a Global Positioning System (GPS) unit. Based on a 28-day incubation period, we revisited nests on or subsequent to the predicted hatch date to determine nest fate, which was categorized as successful, destroyed, or abandoned.

\section{Trapping}

We revisited a subset of active nests found during nest searching 4-5 days prior to predicted hatch dates. This subset included nests evenly distributed in the same habitat described by Didiuk (1979). After flushing the female, we placed a modified bow-style trap (Salyer 1962, Shaiffer and Krapu 1977, Allen 1996, Walter 1999) at the nest. We fired the trap using a remotely triggered system (similar to that described by Shaiffer and Krapu 1977) at distances $<500 \mathrm{~m}$ from the nest.

We fitted trapped females with U. S. Fish and Wildlife Service metal leg bands, orange neck collars (white lettering), and radio transmitters (Advanced Telemetry Systems, Inc., Isanti, Minnesota; use of trade names does not imply endorsement by the U.S. Geological Survey or the University of Minnesota) epoxied to neck collars. We fastened collars around the necks of geese using rivets and vinyl cement (Bond 634, New Herms Inc., Duluth, Georgia) such that the radio transmitter antenna $(12.7 \mathrm{~cm})$ would point down along the bird's breast after release. The total weight of the collar and transmitter was $58 \mathrm{~g}$ ( $<4 \%$ body weight). We measured the culmen, tarsus, skull, gape, wing chord, midwing, and mass of each goose at the time of capture (Moser and Rusch 1988, Dzubin and Cooch 1992).

\section{Radio Telemetry}

We used ground-based telemetry to locate radio-collared females following their departure from nest sites. Initially, we mounted a 13-element directional antenna on a $12.2-\mathrm{m}$ tower to document the presence or absence of radio-collared birds on the study area. The 13-element antenna received signals $\leq 6 \mathrm{~km}$ and permitted telemetry work when poor weather prevented work in the field. We also used two 3-element yagi antennas, each mounted on a $3.1-\mathrm{m}$ piece of conduit to improve the range of signal reception $(\leq 4 \mathrm{~km})$. Prior to fieldwork, we took estimated and true bearings to 5 transmitters to calculate the standard deviation of angle error among these bearings. We used these data in the XYLOG telemetry program (Dodge and Steiner 1986) to estimate transmitter location and a $95 \%$ error ellipse around locations (Dodge and Steiner 1986, White and Garrott 1990). We calculated locations using $\geq 3$ bearings (when possible) taken in the direction halfway between null readings. Receiver station locations were in areas that allowed us to readily locate radio-marked birds (e.g., high points-beach ridges, rocks, etc.). We used 2-way radios to relay receiver locations and animal bearings between observers. Distance between receiver station locations, disturbance to geese in the area, and low manpower prevented investigators from getting 3 bearings on some radiomarked broods. In some of these cases, error ellipses around brood locations were quite large; however, we assigned a habitat type within $95 \%$ error ellipses of estimated point locations based on the bearing direction and receiver station locations. We excluded locations with $95 \%$ error ellipses $>10$ ha.

We used a helicopter (Bell 206 Jet Ranger) equipped with $2 \mathrm{H}-$ antennas, a scanning receiver, and a GPS unit to locate and visually identify radio-collared females from the air. Aerial telemetry flights were flown opportunistically, depending on weather and helicopter availability (range: 1-15 days between flights). We recorded the number of goslings in broods (R. R. Nack, University of Minnesota, St. Paul, Minn., USA, unpublished data) and brood location coordinates. In addition, we flew a 250-m radius circle around the brood location, and we counted the number of light and Canada geese with and without broods in this circle. We flew a second $250-\mathrm{m}$ circle around a point randomly located 500-1000 m away from the brood location to evaluate goose densities in current brood-rearing areas and to assess whether Canada geese were spatially separated from light geese. We located broods and circled as quickly as possible $(\bar{\chi}=12$ minutes from hearing the signal to determining a brood's location) to reduce movements in response to the helicopter.

\section{Vegetation Measurements}

We revisited aerial telemetry locations of radio-marked broods $\geq 4$ weeks postmedian hatch to measure vegetation and describe current brood-rearing habitat. Timing of vegetation measurements coincided with the peak growing period for vegetation in the area (R. L. Jefferies, University of Toronto, Toronto, Ont., Canada, personal communication). We used a $1-\mathrm{m}^{2}$ plot to describe vegetation at the brood location and at 50-m intervals on a transect in a random direction from the brood location. We used a compass to determine the random direction of the transect from the brood location, and we placed the $1-\mathrm{m}^{2}$ plot immediately at the observer's feet after pacing $50 \mathrm{~m}$. We terminated transects at water bodies, beach ridges, distinct changes in vegetation, or at a maximum distance of $200 \mathrm{~m}$. We collected a turf sample $\left(10 \mathrm{~cm}^{2}\right)$ from the center of the $1-\mathrm{m}^{2}$ plot at the brood location. We later reduced $10-\mathrm{cm}^{2}$ turf samples taken in beach ridge/sedge meadow habitat to $7.5 \mathrm{~cm}^{2}$ (Jefferies and Abraham 1994). We calculated above-ground biomass by removing dead material from each 7.5$\mathrm{cm}^{2}$ turf sample and clipping the remaining live vegetation at the sod level. We dried the clipped vegetation at room temperature prior to weighing it (Jefferies and Abraham 1994).

We estimated frequency of occurrence and coverage of vegetation and cover types with the use of an $80-\mathrm{cm}^{2}$ grid, nested within the 1$\mathrm{m}^{2}$ plot. We divided the $80-\mathrm{cm}^{2}$ grid into 16 cells $\left(20 \mathrm{~cm}^{2}\right.$ each $)$ and calculated frequency of occurrence by dividing the number of cells in which the vegetation or cover type was present by the total number of available cells at each brood location. Similarly, we estimated coverage of dominant vegetation or cover types by dividing the 
number of cells in which the vegetation or cover type was dominant (i.e., covered the most surface area) by the total number of available cells at each brood location. Vegetation and cover types included all plant species, bare ground, gravel, and water (similar to Ganter et al. 1996). Frequency of occurrence and coverage measurements were limited to the 4 most extensive vegetation and cover types at each brood location. We also recorded the number of goose feces within the $1-\mathrm{m}^{2}$ plot as a measure of goose activity in the area (Owen 1971, Sutherland and Allport 1994).

We repeated the same vegetation measurements at a paired random point, which we used to evaluate variation within habitat patches used by Canada goose broods within each brood-rearing area. We located random points $>200 \mathrm{~m}$ (when possible) from the brood location and in the same habitat patch and restricted habitat patches to the habitat containing each brood location with boundaries defined by large beach ridges ( $>300 \mathrm{~m}$ wide), lakes $(>2 \mathrm{ha})$, or a dramatic change in vegetation type. Habitat patches most often consisted of large freshwater sedge meadows, beach ridges, or coastal salt marshes; however, we did not analyze vegetation data separately for each habitat type (sedge meadow, beach ridge, salt marsh) because most aerial brood locations were located in freshwater sedge meadows.

\section{Data Analysis}

We assigned initial brood movements to a habitat type by the first telemetry location of the brood $>0.5 \mathrm{~km}$ from the nest site to be certain the brood left the nest. We assumed all successful nesting radio-collared females located on the study area still had broods at that time, unless they were observed without broods. We assigned brood-rearing habitat (salt marsh, beach ridge/sedge meadow, or interior sedge meadow) to individual broods when $\geq 50 \%$ of telemetry locations (ground and aerial-based) occurred in that habitat type. We estimated brood home range size using the animal movement extension in ArcView 3.2a (Environmental Systems Research Institute, Inc., Redlands, California). We used minimum convex polygons to estimate brood home range size from both ground and aerial-based telemetry locations combined, and we compared home range size estimated in our study with historical data (Didiuk 1979, Didiuk and Rusch 1998). We did not include nest locations in estimates of brood home range size because some broods moved a considerable distance from the nest site and did not return.

We compared data collected during aerial telemetry flights at brood locations and paired random points using differences between means (MD) $\pm 95 \%$ confidence intervals (CI) (after Steidl et al. 1997, Johnson 1999); 95\% CI around mean differences that did not include zero suggest significant treatment effects. We evaluated the distribution of light geese in current Canada goose brood-rearing areas with the use of a chi-square test to compare the proportion of observations with zero light geese counted within $250 \mathrm{~m}$ of a Canada goose brood location and a paired random point. We also used chi-square tests to compare initial movements and use of habitat by Canada goose broods between 1976 and 1978 and 2000 and 2002.

We described habitats in current brood-rearing areas by calculating the frequency of occurrence and coverage of each vegetation or cover type found at brood locations and paired random points. We used the mean frequency of occurrence and coverage values for each vegetation or cover type to rank vegetation or cover types in order of abundance and dominance, and reported differences in vegetation measurements collected at brood locations and paired random points in the same habitat patch (above-ground biomass, feces counts, frequency of occurrence, coverage), with the use of $\mathrm{MD} \pm 95 \% \mathrm{CI}$.

\section{Results}

\section{Current Brood Movements}

In 2000 and 2002, spring phenology and weather conditions contributed to 2 of the latest median hatch dates since 1976. In 2000 , sample size of radio-marked geese was small $(n=2)$ and contributed few data used in analyses. However, in 2002, nest density, nest success, and gosling production were not as negatively impacted as expected, based on goose reproduction in previous years with similar phenology (D. E. Andersen, Minnesota Cooperative Fish and Wildlife Research Unit, St. Paul, Minn., USA, unpublished data). Thus, most data included our analyses result from geese monitored in 2001 and 2002.

Forty (57\%) of 70 (all radiomarked geese from 2000 to 2002) radio-marked female Canada geese successfully hatched clutches on the study area (Table 1). The mean interval between departure from nest sites and the initial brood location was 8 days posthatch (range: 2-17 days), and the mean distance traveled from nest sites to the initial brood location was $3.4 \mathrm{~km}(\mathrm{SE}=0.5)$. Initial movements of 30 broods were within the beach ridge/sedge meadow habitat, and 10 geese with broods moved directly to traditional broodrearing areas in salt marsh habitat on the study area.

We documented brood movements and habitat use for 38, 45, and 35 days postmedian hatch in 2000, 2001, and 2002, respectively. Following initial movements to brood-rearing areas, broods made localized movements, generally within the same habitat type. Ten $(38 \%)$ of 26 geese that reared broods in beach ridge/sedge meadow habitat moved to a large sedge meadow-lake complex approximately $4 \mathrm{~km}$ southwest of the study area and eventually moved to coastal salt marsh habitat at approximately 22 days postmedian hatch (Fig. 2). From 2000 to 2002, the proportion of broods using salt marsh, beach ridge/sedge meadow, and interior sedge meadow habitat throughout the brood-rearing period was $0.28,0.65$, and 0.08 , respectively (Table 1 ). The mean 95\% error ellipse around 331 brood locations determined from ground telemetry was 3.5 ha $(\mathrm{SE}=1.5)$.

Unsuccessful nesting females with radio collars $(n=30)$ either left the study area $(n=22)$, or remained on the study area in flocks of unsuccessful nesting or nonbreeding geese $(n=8)$. These results are consistent with those of Didiuk (1979), who reported that

Table 1. Summary of nest fate and habitat use for radio-collared Canada geese with broods near Cape Churchill, Manit., Canada, from 2000-2002.

\begin{tabular}{lrrrr}
\hline Parameter & $\mathbf{2 0 0 0}$ & $\mathbf{2 0 0 1}$ & $\mathbf{2 0 0 2}$ & Total \\
\hline No. trapped & 10 & 31 & 29 & 70 \\
No. hatched clutches & 2 & 26 & 12 & 40 \\
Beach ridge/sedge meadow $^{a}$ & 1 & 16 & 9 & 26 \\
Coastal salt marsh $^{\mathrm{a}}$ & 1 & 8 & 2 & 11 \\
Interior sedge meadow $^{\mathrm{a}}$ & 0 & 2 & 1 & 3 \\
\hline
\end{tabular}

${ }^{a}$ Habitat used during the brood-rearing period. 


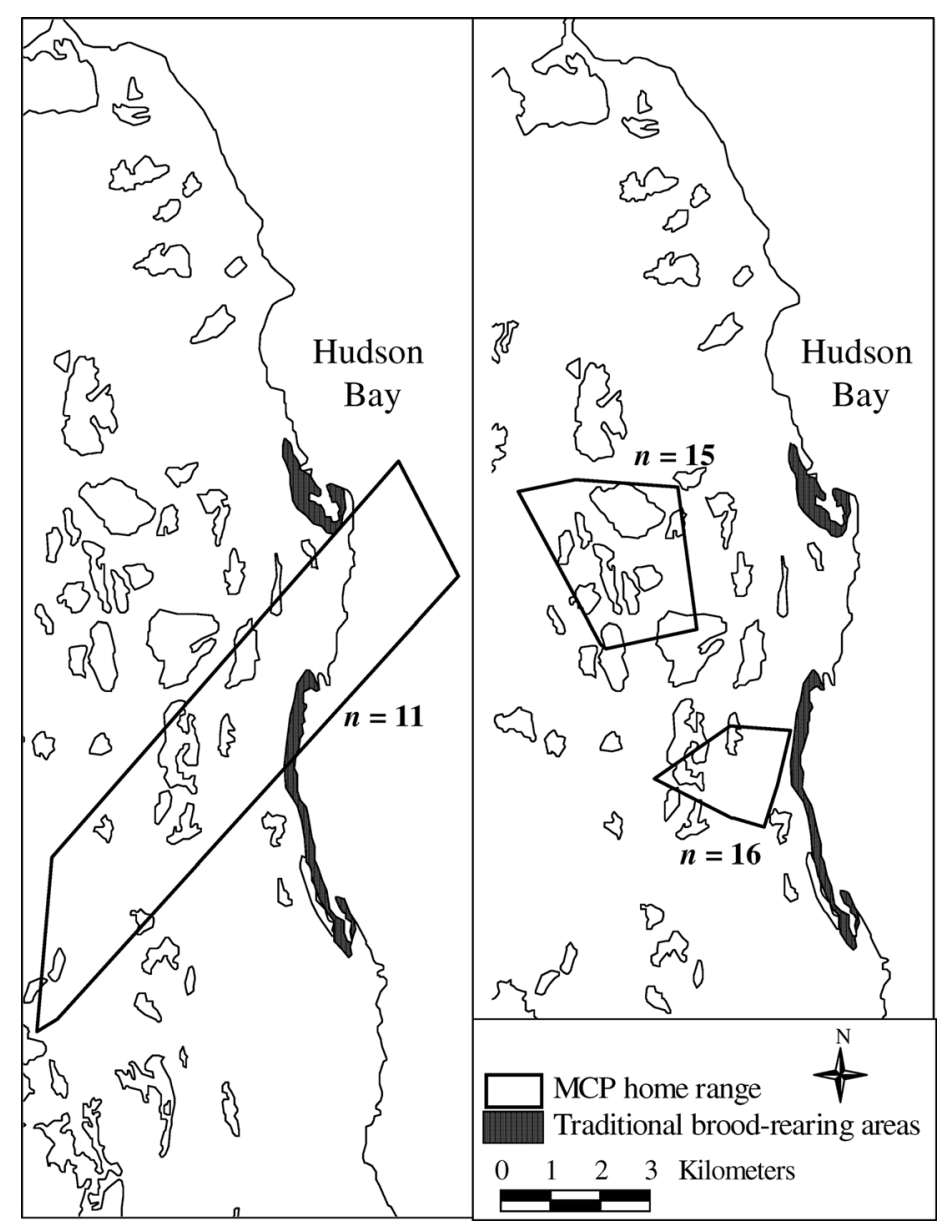

Figure 2. Examples of EPP Canada goose brood home ranges ( $n=$ number of locations) observed from 2000 to 2002 in northern Manit., Canada.

geese failing in reproduction moved to the coast prior to departing on molt migration.

\section{Historical Comparison of Brood Movements}

Initial brood movements from 2000 to 2002 were drastically different from those documented by Didiuk (1979). Didiuk (1979) observed 20 (95\%) of 21 radio-collared geese that were trapped on nests in beach ridge/sedge meadow habitat moving their broods to distinct brood-rearing areas in coastal salt marsh habitat (Table 2) and commented that almost all unmarked family groups moved to these same areas. During 2000-2002, we observed $5(19 \%)$ of 27 geese with broods trapped on nests in the same habitat reported by Didiuk (1979) move to these traditional brood-rearing areas $\left(\chi_{1}^{2}=117.8, P<0.001\right.$; Table 2$)$. Geese with broods that first moved to traditional brood-rearing areas remained in these coastal areas with occasional forays $(<2 \mathrm{~km})$ to inland sedge meadows, which was consistent with the pattern reported by Didiuk (1979). Didiuk (1979) did not search for goose nests in coastal nest-searching units during 1976-1978, so we were unable to compare movements of geese captured and radiomarked at nests in units bordered by Hudson Bay in 2000-2002 ( $n$ $=13$ ) with similar historical data.

In 2000-2002, 12 (30\%) of 40 radiomarked geese with broods were never observed in traditional brood-rearing areas, even though nest sites were located $\leq 4 \mathrm{~km}$ from these areas. Didiuk
Table 2. Habitat type of first telemetry location following hatch and the mean distance $(\mathrm{km})$ traveled away from nest sites by radio-marked Canada geese with broods in 1976-1978 and in 2000-2002 near Cape Churchill, Manit., Canada.

\begin{tabular}{llcccc}
\hline Years & $\boldsymbol{n}^{\text {a }}$ & Salt marsh & $\begin{array}{c}\text { Beach ridge/ } \\
\text { sedge meadow }\end{array}$ & $\overline{\boldsymbol{x}}$ & SE \\
\hline $1976-1978$ & 21 & 20 & 1 & 2.3 & 0.2 \\
$2000-2002$ & 27 & 5 & 22 & 3.4 & 0.5 \\
\hline
\end{tabular}

${ }^{a}$ Canada geese nesting in beach ridge/sedge meadow habitat; excluding coastal areas not searched in 1976-1978.

(1979) did not observe inland movements from nest sites and subsequent movements to coastal salt marsh habitat by radiomarked broods in 1976-1978; however, he did observe unmarked geese with broods $(<25)$ moving toward the coast at $28-35$ days postmedian hatch (Didiuk 1979).

In 1976-1978, radio-marked geese with broods using the beach ridge/sedge meadow habitat had larger mean home ranges at 50 days postmedian hatch than geese with broods using salt-marsh habitat (Didiuk 1979, Didiuk and Rusch 1998). Mean home range size was also larger in beach ridge/sedge meadow habitat than in salt marsh habitat in 2000-2002 (MD = $402 \pm 66 \mathrm{ha})$. The mean brood home range size in 2000-2002 was larger than the mean home range size observed in 1976-1978 in both habitat types (Table 3).

\section{Habitat in Current Brood-Rearing Areas}

We made vegetation and cover measurements at 78 brood locations and paired random points to provide a description of current brood-rearing areas. Vegetation and cover types most frequently found in current brood-rearing areas were sedge (Carex spp.), moss, willow (Salix spp.), tufted bulrush (Scirpus caespitosus), and white mountain aven (Dryas integrifolia). Vegetation and cover types with the most surface area coverage in these same areas were moss, sedge, white mountain aven, willow, and bare ground (Table 4).

There was no difference in the frequency of occurrence for sedge, moss, and white mountain aven between brood locations and random points; however, willow and tufted bulrush occurred more frequently at random points than at the brood location (Table 4). Sedge, moss, and white mountain aven shared equal surface-area coverage at brood locations and paired random points; however, coverage by willow and bare ground was more extensive at random points within habitat patches (Table 4). There was no difference in the number of goose feces $(\mathrm{MD}=0.01$ $\pm 0.52)$ or above-ground biomass $(\mathrm{MD}=0.03 \pm 0.06)$ between brood locations and paired random points.

\section{Distribution of Light Geese}

There was no difference in the mean number of light geese counted within $250 \mathrm{~m}$ of a Canada goose brood location and a paired random point $(\mathrm{MD}=5.31 \pm 5.75)$. Similarly, the proportion of observations with light geese within $250 \mathrm{~m}$ of a Canada goose brood was not significantly different from random points $\left(\chi_{1}^{2}=0.04, P=0.84\right)$. Thus, the distribution of the 40 Canada goose broods we followed did not appear to be influenced by abundance or presence of light geese. 
Table 3. Mean minimum convex polygon home range size (ha) for Canada goose broods near Cape Churchill, Manit., Canada, in 1976-1978 and in $2000-2002$.

\begin{tabular}{|c|c|c|c|c|c|c|c|c|}
\hline \multirow[b]{2}{*}{ Habitat type } & \multicolumn{3}{|c|}{$1976-1978^{a}$} & \multicolumn{3}{|c|}{$2000-2002^{b}$} & \multirow[b]{2}{*}{$\bar{x}$ difference } & \multirow[b]{2}{*}{$95 \% \mathrm{Cl}$} \\
\hline & $n$ & $\bar{x}$ & SE & $n$ & $\bar{x}$ & SE & & \\
\hline Salt marsh & 7 & 297 & 43 & 11 & 617 & 60 & 320 & $(259,381)$ \\
\hline Beach ridge/ sedge meadow & 5 & 584 & 92 & 20 & 1019 & 148 & 435 & $(287,583)$ \\
\hline
\end{tabular}

${ }^{a}$ Mean minimum convex polygon home range through 50 days postmedian hatch date.

b Mean minimum convex polygon home range through 38 (2000), 45 (2001), and 35 (2002) days postmedian hatch date.

\section{Discussion}

Current movements and use of brood-rearing habitat by EPP Canada geese with broods are different from movement and habitat use prior to the presence of light geese on traditional EPP broodrearing areas, and regular nesting by snow geese and extensive habitat alteration on our Cape Churchill study area. The high occurrence and coverage of willow and bare ground at random points suggests Canada goose broods are avoiding the most altered areas within a habitat patch. Highly altered salt marsh habitat in traditional broodrearing areas is currently dominated by moss, willow, and bare ground (L. Punter, University of Manitoba, Winnipeg, Manit., Canada, personal communication); cover and vegetation types that our data indicate Canada goose broods tend to avoid. Habitat alteration, reduced forage availability, and high densities of light geese in traditional brood-rearing areas likely influenced the observed shift in use of brood-rearing habitat to coastal areas south of our study area (Nack and Andersen 2004). Because Canada geese show fidelity to brood-rearing areas and may also breed near areas where they were reared (Zicus 1981, Lessells 1985, Bruggink et al. 1994, Sjoberg and Sjoberg 1998), changes in use of brood-rearing habitat may have contributed to the observed decline in nesting densities of EPP Canada geese near Cape Churchill.

Arctic-nesting geese are known to selectively forage on vegetation high in nutrient content (Owen 1980, Sedinger 1984, Sedinger and Raveling 1984, Gadallah and Jefferies 1995), and numerous studies have attributed reduced growth rates and adult body size in geese to a reduction in the quality or quantity of available forage plants (Sedinger and Raveling 1986, Cooch et al. 1991, Aubin et al. 1993, Leafloor et al. 1998). Hill (1999) found Canada goose goslings (B.c. interior) on Akimiski Island, Nunavut in areas with lesser snow geese to be $20 \%$ lighter and have shorter ninth primary and body length measurements than goslings in areas without lesser snow geese. Hill et al. (2003) observed a significant relationship between band recoveries of goslings in above-average condition and with higher body mass, indicating that only goslings in the best condition survived to fledging and left Akimiski Island. Gosling condition was related to the amount of food resources on the island, and the level of resource availability varied annually (Patton 2001).

Impacts of foraging in freshwater sedge meadow areas by EPP Canada goose broods are not well documented. Use of freshwater sedge meadows by Canada goose broods and no apparent change in adult body size suggests that EPP Canada geese are less reliant on salt marsh vegetation for growth and development than light geese (Walter 1999), or that goslings that forage on poorer quality vegetation do not reach a critical minimum size and are not recruited into the breeding population (Sedinger 1984). However, the mean direct recovery rate for juvenile EPP Canada geese from 1976 to 1984 was $12.6 \%$, compared to $6.5 \%$ from 1985 to 1994 (Leafloor et al. 1996), suggesting that fewer juvenile EPP Canada geese left the breeding grounds during 1985 to 1994 . Gosling growth and survival for EPP Canada geese have not been intensively studied (Leafloor et al. 1996, Walter 1999), but EPP Canada geese that remain faithful to deteriorating brood-rearing habitats may also experience reduced growth and recruitment rates.

A change in the distribution of vegetation necessary for gosling growth and development may explain the 2 -fold increase in brood home range size we observed between 1976 and 1978 and 2000 and 2002. Under current conditions, EPP Canada goose broods may travel farther and forage on less-preferred, lower-quality freshwater species to meet dietary requirements previously met by salt marsh vegetation. This increase in home range size may also result from Canada geese traveling farther to distance themselves from large

Table 4. Mean frequency of occurrence and coverage estimates for vegetation and cover types found in current Canada goose brood-rearing areas near Cape Churchill, Manit., Canada, 2000-2002.

\begin{tabular}{|c|c|c|c|c|c|c|c|}
\hline \multirow[b]{2}{*}{ Cover type } & \multirow[b]{2}{*}{ Parameter } & \multicolumn{2}{|c|}{ Random point } & \multicolumn{2}{|c|}{ Brood location } & \multirow[b]{2}{*}{$\bar{x}$ difference } & \multirow[b]{2}{*}{$95 \% \mathrm{Cl}$} \\
\hline & & $\bar{x}$ & SE & $\bar{x}$ & SE & & \\
\hline \multirow[t]{2}{*}{ Sedge } & Occurrence & 0.70 & 0.04 & 0.69 & 0.04 & 0.01 & $(-0.05,0.07)$ \\
\hline & Coverage & 0.13 & 0.02 & 0.15 & 0.02 & 0.02 & $(-0.01,0.05)$ \\
\hline \multirow[t]{2}{*}{ Moss } & Occurrence & 0.52 & 0.03 & 0.48 & 0.03 & 0.04 & $(-0.03,0.11)$ \\
\hline & Coverage & 0.23 & 0.02 & 0.24 & 0.02 & 0.01 & $(-0.04,0.06)$ \\
\hline \multirow[t]{2}{*}{ Willow } & Occurrence & 0.35 & 0.03 & 0.30 & 0.02 & 0.05 & $(0.00,0.10)$ \\
\hline & Coverage & 0.10 & 0.01 & 0.06 & 0.01 & 0.04 & $(0.01,0.07)$ \\
\hline Tufted bulrush & $\begin{array}{l}\text { Occurrence } \\
\text { Coverage }\end{array}$ & 0.28 & 0.03 & 0.18 & 0.02 & 0.10 & $(0.02,0.18)$ \\
\hline \multirow[t]{2}{*}{ White mountain aven } & Occurrence & 0.23 & 0.04 & 0.16 & 0.04 & 0.08 & $(-0.01,0.17)$ \\
\hline & Coverage & 0.08 & 0.02 & 0.06 & 0.02 & 0.02 & $(-0.01,0.05)$ \\
\hline \multirow[t]{2}{*}{ Bare ground } & Occurrence & & & & & & \\
\hline & Coverage & 0.22 & 0.02 & 0.10 & 0.02 & 0.13 & $(0.08,0.18)$ \\
\hline
\end{tabular}


aggregations or high densities of light geese. We observed no difference between the mean number of light geese counted within $250 \mathrm{~m}$ of Canada goose brood locations and paired random points. However, aerial brood surveys conducted in 2001-2002 along an approximately $75-\mathrm{km}$-long stretch of coastal tundra habitat adjacent to Hudson Bay revealed higher densities of Canada geese with broods in areas with fewer light geese (Nack and Andersen 2004).

Fidelity to brood-rearing areas has been reported in a number of dispersal studies on arctic-nesting geese (Cooke and Abraham 1980, Larsson and Forslund 1992, Lindberg and Sedinger 1997, Ganter and Cooke 1998). Eastern Prairie Population Canada geese with breeding experience exhibit philopatry to particular areas; however, it is unclear if first-time breeders return to the vicinity of natal nest sites or brood-rearing areas to nest (Allen 1996). MacInnes and Lieff (1968) observed distances up to $10 \mathrm{~km}$ between successive nest sites between seasons for cackling geese (Branta butchinsii) at the McConnell River. Walter (1999) hypothesized that EPP Canada geese nesting closer to broodrearing areas at the periphery of our study area than to natal nest sites may be responsible for the observed decline in nest density on the study area. During our study, $13(76 \%)$ of 17 radiomarked Canada geese with broods that nested in the southern half of the study area moved south of the study area, but they remained within $12 \mathrm{~km}$ ( $7.5 \mathrm{mi})$ of nest sites. Aerial brood surveys in 2001 and 2002 indicated that brood densities increased significantly in areas $\geq 15$ km south of our study area since 1976-1978 (Didiuk 1979; Nack and Andersen 2004). Densities of nesting Canada geese at the mouth of the Broad River, $58 \mathrm{~km}$ (36 mi) south of our study area, have increased $26 \%$ from 1987 to 1995 and returned to levels observed in the 1970s (Walter 1999, Humburg et al. 2000). Thus, it is possible that over time, first-time breeders have progressively nested farther south, in proximity to locations where they were reared, rather than returning to breed near natal nest sites.

Our results suggest that the current population size of light geese and the degree of habitat alteration resulting from foraging by light and Canada geese will continue to impact EPP Canada geese on portions of their breeding grounds. Lower nest density, fidelity to brood-rearing areas of low quality, and low gosling survival and growth rates could all affect EPP Canada goose population dynamics, and have implications for how this population is managed.

\section{Management Implications}

Changes in vegetation and ecology of subarctic habitats resulting from intensive foraging by geese have affected EPP Canada

\section{Literature Cited}

Abraham, K. F., and R. L. Jefferies. 1997. High goose populations: causes, impacts, and implications. Pages 7-72 in B. D. J. Batt, editor. Arctic ecosystems in peril: report of the arctic goose habitat working group. Arctic goose joint venture special publication. United States Fish and Wildlife Service, Washington D. C. and Canadian Wildlife Service, Ottawa, Ontario, Canada.

Abraham, K. F., R. L. Jefferies, R. F. Rockwell, and C. D. Maclnnes. 1996. Why are there so many white geese in North America? Pages 79-92 in J. Ratti, editor. Proceedings of the Seventh International Waterfowl Symposium, Memphis, Tennessee, USA.

Allen, B. W. 1996. Movements and nest success of Canada geese in northern Manitoba. Thesis, University of Wisconsin, Madison, USA.

Ankney, C. D. 1996. An embarrassment of riches: too many geese. Journal of Wildlife Management 60:217-223. geese-something that has largely not been incorporated into management paradigms. Trends in breeding population estimates derived from annual aerial breeding ground surveys indicate that the population size of EPP Canada geese has been stationary despite a decrease in nest density near Cape Churchill, an area that occurs within the narrow strip of coastal tundra habitats with historically high breeding density (Humburg et al. 2000). However, managers use EPP Canada geese observed in coastal regions during aerial breeding ground surveys to assess annual production and future breeding potential (Humburg et al. 2000). These production indicators may not adequately reflect recruitment into the fall population if densities of breeding Canada geese continue to decline in coastal regions that are used by large numbers of light geese and that have experienced extensive habitat alteration resulting from goose foraging. Aerial surveys of the EPP Canada goose breeding grounds may need to be modified to assess annual production in coastal regions south of our study area adequately, and management decisions for this population of geese need to consider changes in habitats in coastal regions.

\section{Acknowledgments}

Cooperators of the Minnesota Cooperative Fish and Wildlife Research Unit include the U.S. Geological Survey, the Minnesota Department of Natural Resources, the Wildlife Management Institute, and the University of Minnesota. We thank the numerous field technicians and wildlife biologists who assisted with data collection, including J. Artmann, S. Baldwin, C. W. Boal, R. Bosworth, W. Brininger, K. Burke, B. Christianson, R. Darter, M. Drossel, N. Giessman, J. Henderson, R. Holbrook, T. James, L. Kropf, J. Lane, B. Liddell, T. Luke, G. Lundie, S. Maxson, J. Nack, R. Nack, B. Olson, A. Raedeke, R. Renken, G. Rose, J. E. Sammler, G. Tischer, R. Trine, M. Winfree, J. Wollenberg, and D. Zimmerman. Research at Cape Churchill has been supported financially by the Mississippi Flyway Council's EPP states (Minnesota, Iowa, Missouri, and Arkansas), Manitoba Conservation, Minnesota Cooperative Fish and Wildlife Research Unit, U.S. Geological Survey-Cooperative Research Units, U.S. Fish and Wildlife Service Parks, Canada, and the Canadian Wildlife Service. A. B. Didiuk shared published and unpublished data used in this manuscript, and M. Gillespie saw to the operation of the Nestor One research camp. Wapusk National Park and Hudson Bay Helicopters provided invaluable logistical support. J. S. Lawrence, F. B. Martin, and J. O. Leafloor provided advice regarding project design, assisted with statistical analyses, and read previous drafts of this manuscript.

Aubin, A. E., A. Dzubin, E. H. Dunn, and C. D. Maclnnes. 1993. Effects of summer feeding area on gosling growth in snow geese. Ornis Scandinavica 24:255-260.

Batt, B. D. J., editor. 1997. Arctic ecosystems in peril: report of the arctic goose habitat working group. Arctic Goose Joint Venture Special Publication. United States Fish and Wildlife Service, Washington, D.C. and Canadian Wildlife Service, Ottawa, Ontario, Canada.

Brook, R. K. 2001. Structure and dynamics of the vegetation in Wapusk National Park and the Cape Churchill Wild life Management Area of Manitoba: community and landscape scales. Thesis, University of Manitoba, Winnipeg, Canada.

Bruggink, J. G., T. C. Tacha, J. C. Davies, and K. F. Abraham. 1994. Nesting and brood-rearing ecology of Mississippi Valley Population Canada geese. Wildlife Monograph 126. 
Cooch, E. G., R. L. Jefferies, R. L. Rockwell, and F. Cooke. 1993. Environmental change and the cost of philopatry: an example in the lesser snow goose. Oecologia 93:128-138.

Cooch, E. G., D. B. Lanke, R. F. Rockwell, and F. Cooke. 1991. Long-term decline in body size in a snow goose population: evidence of environmental degradation. Journal of Animal Ecology 60:483-496.

Cooke, F., and K. F. Abraham. 1980. Habitat and locality selection in lesser snow geese: the role of previous experience. Pages 998-1004 in R. Nohring, editor. Acta XVII Congressus Internationalis Ornithologici. Deutschen Ornithologen-Gesellschaft, Berlin, Germany.

Didiuk, A. B. 1979. Movements and distribution of Canada geese near Cape Churchill, Manitoba. Thesis, University of Wisconsin, Madison, USA.

Didiuk, A. B., and D. H. Rusch. 1998. Movements of Canada goose broods near Cape Churchill, Manitoba. Pages 79-85 in D. H. Rusch, M. D. Samuel, D. D. Humburg, and B. D. Sullivan, editors. Biology and management of Canada geese. Proceedings of the International Canada Goose Symposium, Milwaukee, Wisconsin, USA.

Dodge, W. E., and A. J. Steiner. 1986. XYLOG: a computer program for field processing locations of radio-tagged wildlife. United States Fish and Wildlife Service Wildife Technical Report Number 4.

Dzubin, A., and E. G. Cooch. 1992. Measurements of geese: general field methods. California Waterfowl Association. Sacramento, California, USA.

Gadallah, F. L., and R. L. Jefferies. 1995. Forage quality in brood-rearing areas of the lesser snow goose and the growth of captive goslings. Journal of Applied Ecology 32:276-287.

Ganter, B., and F. Cooke. 1998. Colonial nesters in a deteriorating habitat: site fidelity and colony dynamics of lesser snow geese. Auk 115:642-652.

Ganter, B., F. Cooke, and P. Mineau. 1996. Long-term vegetation changes in a snow goose nesting habitat. Canadian Journal of Zoology 74:965-969.

Gleason, J. S., K. F. Abraham, C. D. Ankney, and J. O. Leafloor. 2004. Variation in reproductive performance of Canada geese in the presence and absence of lesser snow geese. Pages 75-83 in T. J. Moser, R. D. Lien, K. C. VerCauteren, K. F. Abraham, D. E. Andersen, J. G. Bruggink, J. M. Coluccy, D. A. Graber, J. O. Leafloor, D. R. Lukkonen, and R. E. Trost, editors. Proceedings of the 2003 International Canada Goose Symposium, Madison, Wisconsin, USA.

Hill, M. R. J. 1999. Factors influencing pre- and post-fledging growth and survival of Canada goose goslings on Akimiski Island, Nunavut. Dissertation, University of Western Ontario, London, Ontario, Canada.

Hill, M. R. J., R. T. Alisauskas, C. D. Ankney, and J. O. Leafloor. 2003. Influence of body size and condition on harvest and survival of juvenile Canada geese. Journal of Wildlife Management 67:530-541.

Humburg, D. D., F. D. Caswell, D. H. Rusch, M. Gillespie, and P. Telander. 2000. Status and trends of the Eastern Prairie Population of Canada geese. Pages 123-135 in K. Dickson, editor. Towards conservation of the diversity of Canada geese (Branta canadensis). Canadian Wildlife Service Occasional Paper 103.

Jano, A. P., R. L. Jefferies, and R. F. Rockwell. 1998. The detection of vegetational change by multitemporal analysis of Landsat data: the effects of goose foraging. Journal of Ecology 86:93-99.

Jefferies, R. L., and K. F. Abraham. 1994. Goose foraging and its effect on plant communities: observations and recording procedures. Report prepared for the Arctic Goose Joint Venture and Canadian Wildlife Service, Ottawa, Ontario, Canada.

Johnson, D. H. 1999. The insignificance of statistical significance testing. Journal of Wildlife Management 63:763-772.

Kotanen, P. M., and R. L. Jefferies. 1997. Long-term destruction of sub-arctic wetland vegetation by lesser snow geese. Ecoscience 4:179-182.

Larsson, K., and P. Forslund. 1992. Genetic and social inheritance of body and egg size in the barnacle goose (Branta leucopsis). Evolution 46:235-244.

Leafloor, J. O., K. F. Abraham, D. H. Rusch, R. K. Ross, and M. R. J. Hill. 1996. Status of the southern James Bay population of Canada geese. Proceedings of the Seventh Annual Waterfowl Symposium, Memphis, Tennessee, USA.

Leafloor, J. O., C. D. Ankney, and D. H. Rusch. 1998. Environmental effects on body size of Canada geese. Auk 115:26-33.

Lessels, C. M. 1985. Natal and breeding dispersal of Canada geese (Branta canadensis). Ibis 127:31-41.

Lindberg, M. S., and J. S. Sedinger. 1997. Ecological consequences of nest site fidelity in black brant. Condor 99:25-38.
Maclnnes, C. D., and B. C. Lieff. 1968. Individual behavior and composition of a local population of Canada geese. Pages 93-101 in R. L. Hine and C. Schoenfield, editors. Canada goose management. Dembar Education Research Services, Madison, Wisconsin, USA.

Malecki, R. A. 1976. The breeding biology of the Eastern Prairie Population of Canada geese. Dissertation, University of Missouri, Columbia, USA.

Moser, T. J., and D. H. Rusch. 1988. Indices of structural size and condition of Canada geese. Journal of Wildlife Management 52:202-208.

Nack, R. R., and D. E. Andersen. 2004. Distribution of Eastern Prairie Population Canada goose broods, 1977-2002: potential influence of snow geese. Pages 130-136 in T. J. Moser, R. D. Lien, K. C. VerCauteren, K. F. Abraham, D. E. Andersen, J. G. Bruggink, J. M. Coluccy, D. A. Graber, J. O. Leafloor, D. R. Lukkonen, and R. E. Trost, editors. Proceedings of the 2003 International Canada Goose Symposium, Madison, Wisconsin, USA.

Owen, M. 1971. The selection of feeding site by white-fronted geese in winter. Journal of Applied Ecology 41:79-92.

Owen, M. 1980. Wild geese of the world. Fakenham Press, Fakenham, Norfolk, United Kingdom.

Patton, K. A. 2001. The effect of body mass and size on late summer survival of Canada goose (Branta canadensis interior) goslings on Akimisk Island, Nunavut. Thesis, University of Western Ontario, London, Ontario, Canada.

Rusch, D. H., F. D. Caswell, M. M. Gillespie, and J. O. Leafloor. 1996. Research contributions to management of Canada geese in the Mississippi Flyway. Proceedings of the North American Wildlife and Natural Resources Conference 61:437-449.

Salyer, J. W. 1962. A bow-net trap for ducks. Journal of Wildlife Management 26:219-221.

Sammler, J. E. 2001. Population trends of tundra-nesting birds in Churchill, Manitoba: potential effects of increasing lesser snow goose (Chen caerulescens caerulescens) populations. Thesis, University of Minnesota, St. Paul, USA.

Sedinger, J. S. 1984. Protein and amino acid composition of tundra vegetation in relation to nutritional requirements of geese. Journal of Wildlife Management 48:1128-1136.

Sedinger, J. S., and D. G. Raveling. 1984. Dietary selectivity in relation to availability and quality of food for goslings of cackling geese. Auk 101:295306.

Sedinger, J. S., and D. G. Raveling. 1986. Timing of nesting by cackling Canada geese in relation to the quality and availability of their food plants. Journal of Animal Ecology 55:1083-1102.

Shaiffer, C. W., and G. L. Krapu. 1977. A remote controlled system for capturing nesting waterfowl. Journal of Wildlife Management 42:668-669.

Sjoberg, K., and G. Sjoberg. 1998. Natal and breeding dispersal in a migratory population of Canada geese in Sweden. Pages 361-366 in D. H. Rusch, M. D. Samuel, D. D. Humburg, and B. D. Sullivan, editors. Biology and management of Canada geese. Proceedings of the International Canada Goose Symposium, Milwaukee, Wisconsin, USA.

Steidl, R. J., J. P. Hayes, and E. Schubauer. 1997. Statistical power analysis in wildlife research. Journal of Wildlife Management 61:270-279.

Sutherland, W. J., and G. A. Allport. 1994. A spatial depletion model of the interaction between bean geese and wigeon with the consequences for habitat management. Journal of Animal Ecology 63:51-59.

Walter, S. E., and D. H. Rusch. 1997. Accuracy of egg flotation in determining age of Canada goose nests. Wildlife Society Bulletin 25:854-857.

Walter, S. E. 1999. Nesting ecology of Eastern Prairie Population Canada geese. Dissertation, University of Wisconsin, Madison, USA.

Wellein, E. G., and H. G. Lumsden. 1964. Northern forests and tundra. Pages 67-76 in J. P. Lunduska, editor. Waterfowl tomorrow. United States Government Printing Office, Washington, D.C., USA.

Weller, M. W. 1956. A simple field candler for waterfowl eggs. Journal of Wildlife Management 20:111-113.

Westerkov, K. 1950. Methods for determining the age of game bird eggs. Journal of Wildlife Management 14:56-57.

White, G. C., and R. A. Garrott. 1990. Analysis of wildlife radio-tracking data. Academic Press, San Diego, California, USA.

Zicus, M. C. 1981. Canada goose brood behavior and survival estimates at Crex Meadows, Wisconsin. Wilson Bulletin 93:207-217.

Associate Editor: Ransom. 